\title{
State Support Mechanisms for Business in the Context of Coronavirus Pandemia
}

\author{
N. N. Belanova ${ }^{1(\bowtie)}$ and A. M. Kuznetsova ${ }^{2}$ \\ ${ }^{1}$ Samara State University of Economics, Samara, Russia \\ bnn371@yandex.ru \\ ${ }^{2}$ Kazan Federal University, Kazan, Russia \\ Alsu@legenda.travel
}

\begin{abstract}
The spread of coronavirus infection and the subsequent introduction of restrictive measures have brought the economy into a new reality that has no examples of implementation in the past. The Russian government is faced with the acute problem of developing and implementing optimal management solutions. The article investigates the main support measures developed by the government of the Russian Federation. The authors compare these measures with measures implemented in other countries. Based on the comparison of the scale of the state participation, it is concluded that it is necessary to expand the package of anti-crisis measures and their preferential financing at the expense of the national welfare fund (NWF).
\end{abstract}

Keywords: Consequences of pandemic $\cdot$ Methods and tools of state influence $\cdot$ State support

\section{Introduction}

The research on the state influence on various spheres of the economy and society is a key focus of many studies. Some researchers analyze development patterns of the state regulation, the others try to establish a relation between the economic growth and the scale of governmental intervention into economy [10]. Researchers do this based on the analysis of empirical data, trying to establish the optimal limits of intervention, but do not see a clear correlation [13]. Some experts identify positive results of interaction between the state and private business [11]. Much attention is paid to the regulation of certain spheres and branches of the economy $[2,7]$.

Supporters of the state regulation highlight the key limitation for the amount of the state support - this is the budget capacity. Therefore, some authors analyze costs of such a regulation [12], investigate problems of public debt and default [8,9]. Despite a wide variety of works on the considered subject, issues of the scope and specific instruments of the state regulation need to be refined and updated, since the spread of coronavirus infection has put the economy in a new reality that has no examples of implementation in the past. 


\section{Methodology}

The methodological basis of this research is formed by fundamental provisions of the economic theory, scientific works of Russian and international scientists in the field of national and world economy. To date, certain methods and tools of the state regulation have been developed in the economic science. However, a comprehensive approach is needed to identify the main areas of support for the national economy and business. In this research, the authors used dialectical, system-functional, economic-statistical, formal-logical and scientific abstraction methods.

\section{Results}

The coronavirus pandemic has a significant impact both on the world and the Russian economies. There is no common position of experts on the pace of the economic decline and the GDP decline. Thus, experts of the state development corporation "VEB" of the Russian Federation ("Vnesheconombank") predict that the GDP will decrease by an average of $3.8 \%$. Specialists of the Institute for strategic analysis ("FBK Grant Thorton") believe that the world economy will decline by 2-3\% compared to the last year, and the Russian GDP - by 10-20\% [1]. According to the forecast of the Central Bank analysts, the GDP decline in the second quarter will be $8 \%$ (because of quarantine restrictions) with a rapid recovery and a year-end decline of 4-6\% [3].

Based on the macroeconomic theory, it can be noted that the GDP by expenditure is calculated using the formula:

$$
\mathrm{GDP}=\mathrm{C}+\mathrm{Ig}+\mathrm{G}+\mathrm{Xn}
$$

$\mathrm{C}$ - consumer expenditure,

$\mathrm{Ig}$ - gross investment expenditure,

$\mathrm{G}$ - government expenditure,

$\mathrm{Xn}$ - net exports (the difference between exports and imports).

Changes in the GDP occur as a result of changes in these components:

$$
\Delta \mathrm{GDP}=\Delta \mathrm{C}+\Delta \mathrm{Ig}+\Delta \mathrm{G}+\Delta \mathrm{Xn}
$$

According to the forecast of the Central Bank specialists, investments in fixed assets will decrease by $6-8 \%$ this year, and exports will fall by $10-15 \%$. It is difficult to estimate the fall in consumer expenditure, but given the increase in the unemployment rate to $7 \%$ on average over the year and the fall in disposable income by $6.5 \%(17.5 \%$ in the second quarter), we can assume that even an optimistic forecast will make it $8-10 \%$.

Government expenditure $(\mathrm{G})$ can be considered as the only limiting factor for the fall in the GDP from the analyzed components. In crisis development periods, when most macroeconomic indicators are declining and the market economy does not provide optimal development rates, the state actively intervenes, increasing expenditures, and thus partially compensating for the fall in the remaining components of the 
GDP. However, according to the Central Bank chairman E.S. Nabiullina, declared and implemented by the current government measures will support the GDP by only $2 \%$ [3]. According to the head of the Accounting Chamber A. Kudrin, the overall package of the state support measures should be at least 7\% of the Russian GDP.

Further, we consider measures that the Russian Government has developed to support the economic development [4]:

1. Loans and grants for business (interest-free credit for payment of wages, grants for payment of salaries and other urgent issues, if at least $90 \%$ of the staff remain the same, and $2 / 3$ of interest payments on new loans are covered by the state and banks).

2. Deferral and reduction of taxes (except VAT) and insurance payments for 6 months for small and medium-sized businesses in the most affected industries. For other organizations, the insurance premiums will be reduced by half for the amount of wages exceeding the minimum wage.

3. Deferred lease payments for state and municipal property.

4. Moratorium on the initiation of bankruptcy cases on applications from creditors for system-forming enterprises and organizations of the most affected industries. The most affected industries include road transport, air transport, tourism, exhibition activities, entertainment and leisure, culture and sports, public catering, and nonfood retail. This list was approved by a government decree and can be expanded [5].

2. Reducing the administrative burden by:

- automatic renewal of 15 types of licenses and permits that expire in 2020;

- simplifying the conclusion of public contracts, easier requirements for public procurement;

- providing a "green corridor" for imported essential goods, introducing a simplified procedure for certification of imported products and abolishing customs duties on medicinal and medical products that serve to prevent the spread of coronavirus;

- reducing unproductive business costs by introducing a moratorium on inspections, control is planned to be carried out remotely: in the format of audio and video communications;

- cancellation of fines and penalties for contracts executed in 2020.

Support measures for the backbone enterprises include:

- granting preferential loans for 1 year to maintain working capital and save jobs;

- weekly monitoring of enterprises, stress testing and, if necessary, providing targeted support.

Let's consider the practice of applying various forms of the state support during the coronavirus pandemic by individual countries (Table 1).

The conducted analysis shows that he state support measures are implemented mainly in the credit sphere (preferential lending, provision of state guarantees, etc.) and in the tax sphere (reduction of tax rates, provision of deferred tax payments). We have conducted a comparative analysis of the amount of the state support in different countries. 
Table 1. Government support for business during the coronavirus pandemic in various countries

\begin{tabular}{|c|c|c|c|c|}
\hline $\begin{array}{l}\text { Support } \\
\text { direction }\end{array}$ & China & Great Britain & Sweden & Canada \\
\hline Credit area & $\begin{array}{l}\text { Loans for tax } \\
\text { debts, } \\
\text { simplification of } \\
\text { the procedure } \\
\text { for issuing loans }\end{array}$ & $\begin{array}{l}\text { Interest-free } \\
\text { loans for up to } 1 \\
\text { year, credit and } \\
\text { financial } \\
\text { guarantees }\end{array}$ & $\begin{array}{l}\text { Increased } \\
\text { credit resources } \\
\text { and state } \\
\text { guarantees, } \\
\text { special support } \\
\text { for export } \\
\text { industries }\end{array}$ & $\begin{array}{l}\text { Affordable } \\
\text { business loans } \\
\text { and interest-free } \\
\text { loans to cover } \\
\text { operating } \\
\text { expenses, } \\
\text { issuing } \\
\text { preferential loans } \\
\text { to the lessee for } \\
\text { reducing rental } \\
\text { rates }\end{array}$ \\
\hline Tax area & $\begin{array}{l}\text { Reduction of } \\
\text { taxes (VAT, } \\
\text { income tax, } \\
\text { cancellation of } \\
\text { insurance and } \\
\text { social benefits } \\
\text { for employers) }\end{array}$ & $\begin{array}{l}\text { Tax benefits, } \\
\text { deferred VAT } \\
\text { payments, tax } \\
\text { holidays until the } \\
\text { end of } 2021 \text { for } \\
\text { certain industries }\end{array}$ & $\begin{array}{l}\text { Deferred } \\
\text { payment of } \\
\text { social } \\
\text { insurance } \\
\text { contributions, } \\
\text { payroll tax, } \\
\text { VAT }\end{array}$ & $\begin{array}{l}\text { Deferred income } \\
\text { tax, federal } \\
\text { goods and } \\
\text { services tax, and } \\
\text { sales tax }\end{array}$ \\
\hline $\begin{array}{l}\text { Gratuitous } \\
\text { financial } \\
\text { support, } \\
\text { grants and } \\
\text { state } \\
\text { investment }\end{array}$ & $\begin{array}{l}\text { Investment in } \\
\text { industries that } \\
\text { create jobs }\end{array}$ & $\begin{array}{l}\text { Grants to cover } \\
\text { current business } \\
\text { costs, } \\
\text { government } \\
\text { payment of } 80 \% \\
\text { of employees' } \\
\text { wages for } 3 \\
\text { months } \\
\text { (maximum } \\
\text { amount of } \\
2500 \text { lb per } \\
\text { month) }\end{array}$ & $\begin{array}{l}\text { SEK } 1 \text { million } \\
\text { is allocated to } \\
\text { support culture } \\
\text { and sports }\end{array}$ & $\begin{array}{l}\text { Subsidizing } 75 \% \\
\text { of employees' } \\
\text { wages (up to } \$ \\
874 \text { per week), } \\
\text { for individual } \\
\text { enterprises - } \\
100 \% \\
\text { compensation of } \\
\text { employees' } \\
\text { pension and } \\
\text { social insurance } \\
\text { contributions }\end{array}$ \\
\hline $\begin{array}{l}\text { Monetary } \\
\text { policy }\end{array}$ & $\begin{array}{l}\text { Reducing the } \\
\text { mandatory } \\
\text { reserve ratio for } \\
\text { small and } \\
\text { medium-sized } \\
\text { banks, } \\
\text { increasing the } \\
\text { availability of } \\
\text { funds }\end{array}$ & $\begin{array}{l}\text { Ensuring } \\
\text { financial stability } \\
\text { and credit } \\
\text { availability }\end{array}$ & $\begin{array}{l}\text { Ensuring } \\
\text { financial } \\
\text { stability and } \\
\text { credit } \\
\text { availability }\end{array}$ & $\begin{array}{l}\text { Reducing } \\
\text { interest rates, } \\
\text { supporting the } \\
\text { financial market } \\
\text { and liquidity of } \\
\text { financial } \\
\text { institutions }\end{array}$ \\
\hline
\end{tabular}

Source: authors.

Figure 1 shows that, in Russia, the scale of funding for state anti-crisis measures is the lowest (about $1.2 \%$ of the GDP). Almost all developed countries have undertaken 
significant anti-crisis programs, including the use of various monetary and fiscal policy instruments. This is because of the high risk of losses on the part of the economy if SMEs leave the market not having any reserves. A reduction in the production, a sharp increase in unemployment, in poverty, and a reduction in real income will reduce the demand. For a clear demonstration of this development of negative consequences, let's consider the macroeconomic equilibrium graph (Fig. 2).

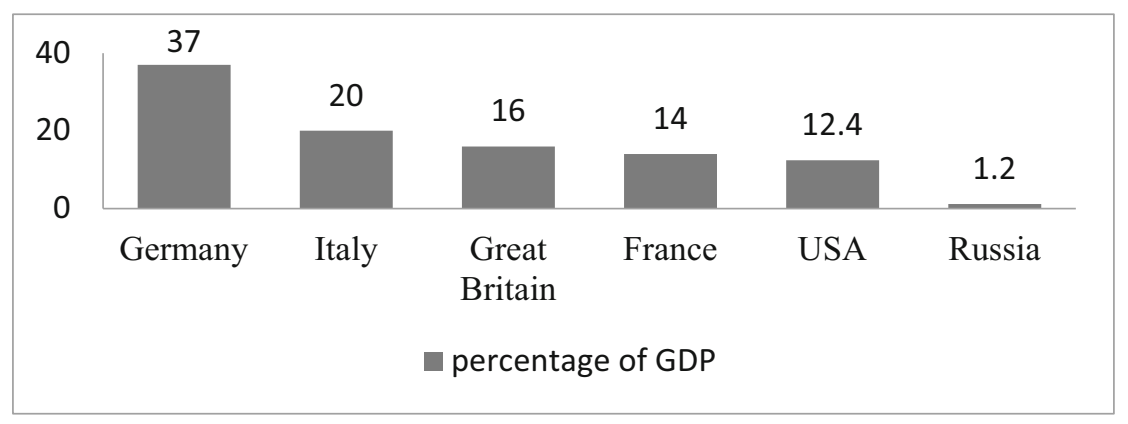

Fig. 1. Comparative scale of anti-crisis measures in Russia and other countries (as a percentage of the GDP). (Source)

Forced self-isolation during the pandemic led to the closure of most businesses. Disruption of production and economic chains and lack of working capital create a high risk of falling production volumes in the economy, which shifts the supply curve from AS1 to AS2. If aggregate demand remains constant, this leads to a decrease in real output (from $\mathrm{GDP}_{\mathrm{E} 1}$ to $\mathrm{GDP}_{2}$ ) and an increase in the price level from r1 to $\mathrm{r}$. However, under current conditions, aggregate demand is also decreasing (as a result of increased unemployment and lower real incomes), which further reduces the real output.

Graphically, this is reflected by the shift of the curve from $\mathrm{AD}_{1}$ to $\mathrm{AD}_{2}$, the equilibrium point from $\mathrm{E}_{1}$ to $\mathrm{E}_{2}$, and a significant decrease in production volumes from $\mathrm{GDP}_{\mathrm{E} 1}$ to $\mathrm{GDP}_{\mathrm{E} 2}$. The negative impact on macroeconomic processes occurs both from the factors of aggregate demand and from the factors of aggregate supply.

The high probability of threats being realized and significant losses being incurred forces countries to incur significant financial costs, since it is strategically more profitable to stop the main mechanisms of the crisis spreading at an early development stage than to deal with its negative consequences in the future.

Developing countries are taking more modest anti-crisis measures, but this is explained not so much by the required amount of financial support, but rather by the budgetary capabilities of a state.

For the Russian Government, the priority is to determine needs of the market and its individual subjects for the state support. The development of crisis phenomena in the Russian economy can be much more serious, as the situation is aggravated by the raw material orientation of the economy; that in turn, because of a sharp decline in demand 


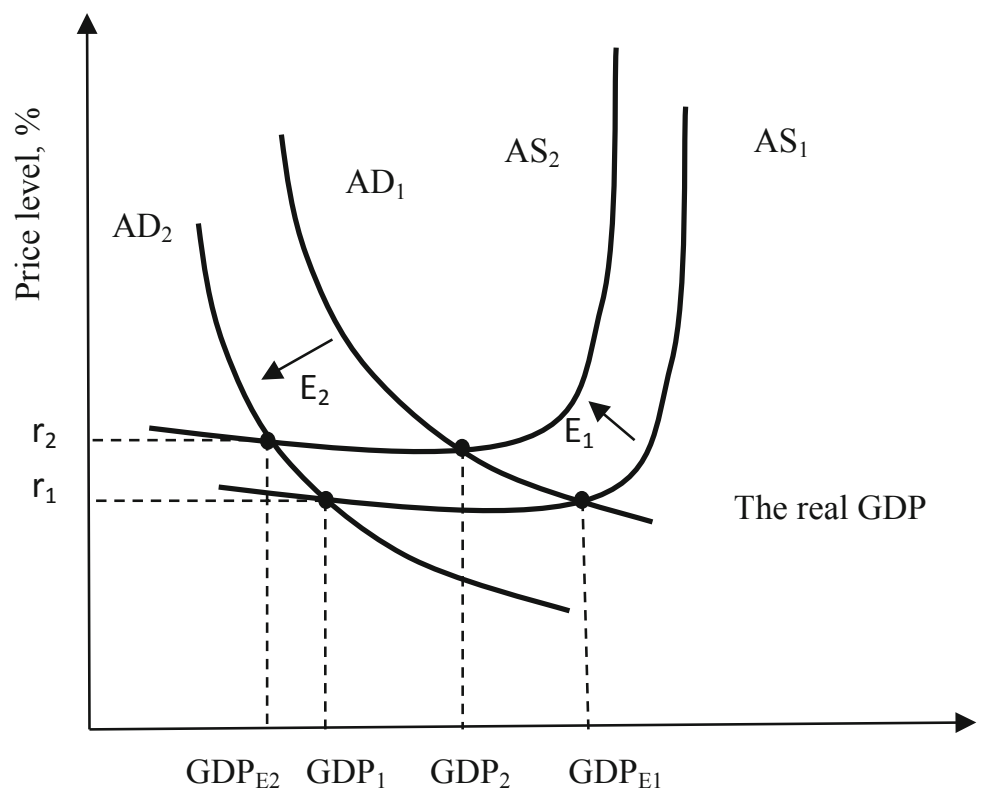

Fig. 2. Macroeconomic equilibrium (Source: authors)

for hydrocarbons, falling oil prices on the world market, will lead to a decrease in the revenue part of the budget.

In our view, the package of anti-crisis measures should be expanded and the scale of financial support from the state should be increased. This is possible as due to the use of funds from the National Welfare Fund (NWF), as well as various monetary and fiscal policy instruments.

In recent years, a strict budget policy has been implemented with the formation of a budget surplus, which will now cover some of the unexpected budget expenditures and budget deficits resulting from the crisis. In our opinion, the funds of the NWF should be used primarily for theses purposes. By April 1, 2020, the federal budget amounted to 12 trillion 855.75 billion rubles, or $11.3 \%$ of the GDP. The volume of liquid assets of the fund (funds on bank accounts of the Bank of Russia) amounted to 11,095 trillion rubles (9.8\% of the GDP) [6]. Besides, additional budget expenditures can be financed by additional issue of government securities.

Analyzing the package of the Russian anti-crisis measures, it can be noted that the state has mainly limited itself to measures not related to direct expenditures (tax deferrals, state guarantees on loans, etc.). In our view, the state should more actively provide fiscal support to businesses by providing direct subsidies and providing free financial resources to strategically important and system-forming enterprises in case of crisis situations. 


\section{Discussion}

Currently, the economy of Russia and the world economy are going through a crisis. In order to avoid the stage of a prolonged depression, government actions are necessary to revive the markets, maintain the business activity level by increasing public spending, that is, it is necessary to implement a policy of fiscal expansion. The development and implementation of budget policy are determined by goals and objectives of the society. At the same time, a balance should be maintained between public needs and the financial capacity of the state budget. A balanced state budget is an ideal development option, but it is often unattainable. The state's decision on the size of the state budget deficit should be based on an analysis of short- and medium-term development prospects. The choice of specific ways to cover the budget deficit should be based on the analysis of comparative advantages and possible consequences of alternatives.

\section{Conclusion}

The development of crisis phenomena in the world and Russian economies as a result of the spread of coronavirus infection and the application of restrictive measures puts states in need of rapid anti-crisis decisions. The analysis of methods and tools of the state regulation conducted in this work has shown that the main areas of influence are the tax and credit spheres. The Russian government has mostly limited itself to measures that are not related to direct expenditures (tax deferrals, state guarantees on loans, etc.). In our view, it should more actively implement fiscal expansion, providing direct subsidies and free financial resources to strategically important and system-forming enterprises. Currently, the share of anti-crisis government spending in the GDP is $1.2 \%$, and it is planned to increase it to $4-5 \%$. However, in our view, this is not enough. The state should more actively use fiscal policy tools, covering additional expenses at the base of the National Welfare Fund or placing government bonds on the open market. This policy may lead to a state budget deficit, but it will help to stop the main mechanisms of crisis spreading at an early stage of its development, prevent the development of a crisis phenomena spiral, which will allow us to achieve sustainable growth rates in the long term.

\section{References}

1. Bank of Russia: Bulletin of the Department for Research and Forecasting (2020). https:// www.cbr.ru/Collection/Collection/File/27780/bulletin_20-02.pdf. Accessed 10 May 2020

2. Domrachev, T.B.: State and non-state support for the development of construction enterprises. Eng. Pers. Future Russia's Innov. Econ. 6, 43-45 (2017)

3. Starostina, Yu.: Official Central Bank forecast for the Russian GDP (2020). https://www.rbc. $\mathrm{ru} / \mathrm{economics} / 24 / 04 / 2020 / 5$ ea19aff9a7947282c785981. Accessed 10 May 2020

4. Plan to overcome the economic consequences of a new coronavirus infection (prepared by the Government of the Russian Federation). https://www.economy.gov.ru/material/dokumenty/ plan_preodoleniya_ekonomicheskih_posledstviy_novoy_koronavirusnoy_infekcii.html. Accessed 10 May 2020 (2020) 
5. Resolution of the Government of the Russian Federation of 03.04.2020 N 434 (ed. from 18.04.2020) "On approval of the list of sectors of the Russian economy that are most affected by the deterioration of the situation as a result of the spread of a new coronavirus infection" (2020). https://www.minfin.ru/ru/document/?id_4=117699-svedeniya_o_razmeshchenii_ sredstv_fnb_na_depozitakh_veb.rf_po_sostoyaniyu_na_1_aprelya_2020_goda. Accessed 10 May 2020

6. Teryutina, M.M., Tarasov, M.E., Sleptsov, I.I.: State regulation and state support of the agricultural sector of the economy. Econ. Entrepreneurship 9(86), 365-367 (2017)

7. Cuadrado-Ballesteros, B.: Do progressive governments undertake different debt burdens? partisan vs. electoral cycles ¿Se endeudan más los partidos progresistas? ciclo partidista vs. ciclo electoral. Revista de Contabilidad 14(1), 29-57 (2011). https://doi.org/10.1016/s11384891(11)70021-8

8. Giordano, R., Tommasino, P.: What determines debt intolerance? The role of political and monetary institutions. Euro. J. Polit. Econ. 27(3), 471-484 (2016). https://doi.org/10.1016/j. ejpoleco.2011.02.001

9. Heckelman, J., Wilson, B.: The growth-maximizing level of regulation: evidence from a panel international data. Euro. J. Polit. Econ. 59, 354-368 (2019). https://doi.org/10.1016/j. ejpoleco.2019.05.001

10. Huanyong, J., Miao, Z.: Corporate social responsibility and collaborative innovation: the role of government support. J. Cleaner Produc. 260, 121028 (2020). https://doi.org/10.1016/ j.jclepro.2020.121028

11. Kearl, J.R.: Rules, rule intermediaries and the complexity and stability of regulation. J. Public Econ. 22(2), 215-226 (1983). https://doi.org/10.1016/0047-2727(83)90066-X

12. Scuotto, V., Del Giudice, M., Tarba, S., Messeni Petruzzelli, A., Chang, V.: International social SMEs in emerging countries: do governments support their international growth? J. World Bus. (2019, in press). https://www.sciencedirect.com/science/article/pii/S10909 51618301585. Accessed 10 May 2020

13. Polat, Z.A., Alkan, M.: The role of government in land registry and cadastre service in Turkey: towards a government 3.0 perspective. Land Use Policy 92, 104500 (2020). https:// doi.org/10.1016/j.landusepol.2020.104500 